\title{
Maize biofortification and yield improvement through organic biochemical nutrient management
}

\author{
Biofortificación y aumento del rendimiento del maíz a través \\ del manejo bioquímico de los nutrientes orgánicos \\ Elnaz Davaran Hagh ${ }^{1 *}$, Bahram Mirshekari ${ }^{1}$, Mohammad Reza Ardakani², \\ Farhad Farahvash', Farhad Rejali ${ }^{3}$
}

\begin{abstract}
Micronutrient malnutrition is a threatening health issue mainly among the developing countries. Thus cereal biofortification must be under attention of researchers in addition to yield improvement in order to feed the increasing world population. In order to investigate the effects of various sources of nutrients on maize biofortification, growth and yield, a field experiment was conducted at the research station of the Faculty of Agriculture, Islamic Azad University, Tabriz, Iran in 2012. The experiment was carried out as a randomized complete block design with a factorial arrangement in 3 replicates. Studied factors (4 factors) were Vermicompost (V 0 and V1), inoculation with and without Thiobacillus thiooxidans (B 0 and B 1), Fe chelate foliar spraying ( $\mathrm{F} 0$ and F 1) and Zn chelate foliar application ( $\mathrm{Z} 0$ and Z 1). The results showed that maize grain yield was improved by application of vermicompost (20.9\%) and inoculation with Thiobacillus (13.1\%). Biofortification demonstrated that vermicompost and Thiobacillus were highly effective on the micronutrient content of grain, improving Fe (12.7\% and $12.1 \%$, respectively) and $\mathrm{Zn}(29.2 \%$ and $17.5 \%$, respectively) content. Although Fe and $\mathrm{Zn}$ application improved grain yield slightly (5.8\% and $8.0 \%$, respectively), they were effective for maize biofortification. Although $\mathrm{Fe}$ and $\mathrm{Zn}$ foliar application had slight effects on plant yield, yet Fe application increased Fe content by $12.9 \%$. However, $\mathrm{Zn}$ application increased the content of $\mathrm{N}$ by $6.7 \%, \mathrm{Zn}$ by $12.6 \%$ and protein by $7.2 \%$. Farmers must be encouraged to apply micronutrient fertilizers to their fields in order to increase the quality of their products.
\end{abstract}

Key words: iron, Thiobacillus, vermicompost, Zea mays, zinc.

\section{RESUMEN}

La desnutrición es un problema de salud que amenaza principalmente a los países en vías de desarrollo. La investigación orientada al mejoramiento de los cereales por el bioenriquecimiento permite mejorar la alimentación de la población mundial en situación de vulnerabilidad alimenticia. El objetivo de esta investigación es evaluar distintas fuentes de nutrientes en maíz bioenriquecido en el desarrollo y rendimiento del cereal. El experimento de campo se realizó en el campo de investigación de la Facultad de Agronomía de la Universidad Islámica Azad, Tabriz, Irán, durante 2012. El diseño experimental fue un diseño de bloques completos al azar con un arreglo factorial y tres repeticiones. Los factores estudiados fueron compost de lombriz (VO y V1); inoculación con Thiobacillus thiooxidans (BO y B1), Fe quelatado en pulverización foliar ( FO y F1) y Zn quelatado en aplicación foliar (ZO y Z1). Los resultados mostraron que el rendimiento de grano de maíz mejora mediante la aplicación de vermicompost (20,9\%) y con inoculación de Thiobacillus (13,1\%). Los resultados indican que los cultivos en vermicompost con aplicación de Thiobacillus fueron muy eficaces en el aumento de contenido de micronutrientes de grano, con mejora de Fe (12,7\% y 12,1\%, respectivamente) y Zn (29,2\% y 17,5\%, respectivamente). Aunque la aplicación Fe y Zn mejoró el rendimiento de grano ligeramente $(5,8 \%$ y 8,0\%, respectivamente) fueron eficaces para bioenriquecimiento maíz. Pese a que la aplicación foliar de Fe y Zn tuvo efectos leves sobre el rendimiento de la planta, la aplicación de Fe aumentó el contenido hierro en el maíz en 12,9\%. La aplicación de Zn aumentó el contenido de N en 6,7\%; Zn en 12,6\% y proteína en 7,2\%. Los resultados sugieren que se deben estimular a los agricultores la aplicación de micronutrientes para mejorar la calidad de sus productos.

Palabras clave: hierro, Thiobacillus, humus de lombriz, Zea mays, zinc.

\section{Introduction}

Half the world's population suffers from micronutrient malnutrition. Enrichment of food crops, especially cereals which are broadly consumed worldwide, may help to cope with the problem. One of the methods to enrich cereals with micronutrients is plant nutrient management. Nutrient management also determines the success or failure of an intensive crop production system. Application of chemical

\footnotetext{
1 Department of Agronomy and Plant Breeding, Tabriz Branch, Islamic Azad University. Tabriz, Iran.

2 Department of Agronomy and Plant Breeding, Karaj Branch, Islamic Azad University. Karaj, Iran.

3 Soil and Water Research Institute. Karaj, Iran.

* Correponding author: mirshekari@iaut.ac.ir
}

Fecha de Recepción: 27 Abril, 2016.

Fecha de Aceptación: 31 Agosto, 2016.

DOI: $10.4067 /$ S0718-34292016005000026 
fertilizers resulted in the boost of agricultural production in the last century; however, if continued for longer it would leave adverse effects on the environment and all life forms on Earth including humans and livestock. In fact, agriculture is a major source of environmental pollution due to extensive use of chemical inputs (Cho et al., 2008; Bouis and Welch, 2010; Garnier et al., 2010).

After chemical fertilizers, the option was biofertilizers and other non-chemical sources of nutrients such as farmyard manures, green manures, compost and vermicompost. However, soon it was found that application of the non-chemical sources alone is not profitable and cannot support the nutritional requirements of high yielding cultivars. Therefore, a new idea emerged to consider both ecological conservation and human need for surplus food, called Integrated Nutrient Management (INM). INM, an environmentallyfriendly approach, combines all possible sources of nutrients from chemicals to non-chemicals to sustain plant nutrition, improve soil fertility and preserve the environment (Prasad et al., 2002; Cho et al., 2008; Gopalasundaram et al., 2012).

Iron $(\mathrm{Fe})$ and zinc $(\mathrm{Zn})$ are two heavy metal micronutrients playing vital roles in plants. Although present in soil, their availability to plant roots is limited because of complicated soil processes and conditions (Wiedenhoeft, 2006; Cakmak, 2008). Thus the method of $\mathrm{Zn}$ and $\mathrm{Fe}$ application is highly important; foliar application can help faster and higher absorption rate and cure deficiency symptoms. This can also be an effective method in biofortification of food crops. Yuan et al. (2012) tested the effect of $\mathrm{Fe}$ and $\mathrm{Zn}$ foliar application on yield and quality of rice cultivars. They found an average of $14.5 \%$ enhancement in Fe concentration of all rice cultivars. They also found improvement in grain yield, protein content and total amino acid content as the result of $\mathrm{Fe}$ and $\mathrm{Zn}$ spraying. Pareek and Poonia (2011) reported that pod and haulm yield of groundnut increased by 14.84 and $11.2 \%$ with foliar Fe application. Sawan et al. (2001) also reported that foliar $\mathrm{Zn}$ application increased cotton seed yield by $8.4 \%$.

Vermicompost, a finely-divided peat-like material with high porosity, aeration, water holding capacity and microbial activity, is produced by earthworms and microorganisms through breakdown, mineralization and stabilization of various organic materials (Dominguez, 2004; Singh et al., 2008;
Chander et al., 2013). This organic source of nutrients has been under attention in recent years. Lazcano et al. (2011) tested the response of 4 sweet corn hybrids to vermicompost and reported that the treatment significantly improved plant growth, marketable yield and the quality of ears. However, the level of improvement varied with the hybrid. They concluded that the different response of hybrids to the vermicompost represents a complex interaction between organic amendments and plants. In Iran, because of lime originated soils and high $\mathrm{pH}$, the efficiency of chemical fertilizers, especially phosphorus fertilizers and micronutrients containing fertilizers, is very low after adding to soil.

Thiobacillus is a chemolithotroph bacterium; receiving energy from sulfur oxidation. Activity of this bacterium acidifies microsites in the rhizosphere, increasing the availability of nutrients to plant roots (Killham, 1994). Suitable soil properties including fertility level, temperature, moisture, $\mathrm{pH}$, salinity and organic materials positively affect sulfur oxidation by Thiobacillus. Aria et al. (2010) reported that Thiobacillus thiooxidans inoculation increased water soluble phosphorus in soil by releasing it from hard rock phosphate.

To examine the benefits of integrated nutrient management, this experiment was conducted with the aim of testing the effect of $\mathrm{Fe}$ and $\mathrm{Zn}$ foliar spraying, Thiobacillus thiooxidans inoculation and vermicompost application on growth, yield and biofortification of popcorn maize.

\section{Materials and Methods}

Experimental Design, Plant Culture and Management. The experiment was conducted in 2012 at the Research Station of the Faculty of Agriculture, Islamic Azad University, Tabriz branch, Iran, $\left(46^{\circ} 17^{\prime} \mathrm{E}, 38^{\circ} 5^{\prime} \mathrm{N}\right)$. The test site field was under potato-wheat rotation in the previous cropping seasons. Soil properties were $1.15 \%$ organic matter content, $14 \%$ clay, $16 \%$ silt, $70 \%$ sand, $\mathrm{pH}=8.05$ and $\mathrm{CEC}=1.55\left(\mathrm{ds}^{*} \mathrm{~m}^{-1}\right)$. Other soil properties are listed in Table 1. The experiment was conducted as a Randomized Complete Block Design (RCBD) with a factorial treatment arrangement and 3 replications and 4 treatments:

Vermicompost. With $\left(\mathrm{V}_{1}\right)$ and without $\left(\mathrm{V}_{0}\right)$ application of $2 \mathrm{t}^{*} \mathrm{ha}^{-1}$ vermicompost, applied in strip form below the seeds before cultivation. The source of the vermicompost was cow manure. 
Table 1. Properties of the test site soil.

\begin{tabular}{cccccccccr}
\hline Depth $(\mathrm{cm})$ & $\begin{array}{c}\text { OC } \\
(\%)\end{array}$ & $\begin{array}{c}\text { TNV } \\
(\%)\end{array}$ & $\begin{array}{c}\text { Total N } \\
(\%)\end{array}$ & $\begin{array}{c}\mathrm{P} \\
(\mathrm{ppm})\end{array}$ & $\begin{array}{c}\mathrm{K} \\
(\mathrm{ppm})\end{array}$ & $\begin{array}{c}\mathrm{Fe} \\
\left(\mathrm{mg}^{*} \mathrm{~kg}^{-1}\right)\end{array}$ & $\begin{array}{c}\mathrm{Mn} \\
\left(\mathrm{mg}^{*} \mathrm{~kg}^{-1}\right)\end{array}$ & $\begin{array}{c}\mathrm{Zn} \\
\left(\mathrm{mg}^{*} \mathrm{~kg}^{-1}\right)\end{array}$ & $\begin{array}{c}\mathrm{Cu} \\
\left(\mathrm{mg}^{*} \mathrm{~kg}^{-1}\right)\end{array}$ \\
\hline $0-30$ & 1.15 & 11.25 & 0.126 & 15.7 & 370 & 4.2 & 3.6 & 1.1 & 0.96 \\
\hline
\end{tabular}

Thiobacillus inoculation. With $\left(\mathrm{B}_{1}\right)$ and without $\left(\mathrm{B}_{0}\right)$ inoculation of Thiobacillus thiooxidans with a population of $10^{8} \mathrm{cfu}^{*} \mathrm{~g}^{-1}$. Sulfur was inoculated with $3 \mathrm{~kg}^{*} \mathrm{ha}^{-1}$ T. thiooxidans prior to application. The inoculum was obtained from the Soil and Water Research Institute, Karaj, Iran.

Iron foliar application. With $\left(\mathrm{F}_{1}\right)$ and without $\left(\mathrm{F}_{0}\right) \mathrm{Fe}$ chelate foliar spraying. The $13 \% \mathrm{Fe}$ chelate (Green ${ }^{\circledR}$, Italy) was applied as 0.002 ounce at tassel appearance stage and again after 2 weeks.

Zinc foliar application. With $\left(Z_{1}\right)$ and without $\left(\mathrm{Z}_{0}\right) \mathrm{Zn}$ chelate foliar spraying. The $15 \% \mathrm{Zn}$ chelate (Green ${ }^{\circledR}$, Italy) was applied as 0.002 once at tassel appearance stage and again after 2 weeks.

The vermicompost used in this experiment was also analyzed for its properties (Table 2). It had $\mathrm{pH}$ $7.4, \mathrm{C} / \mathrm{N}$ ratio of 21 and $40 \%$ organic matter content.

Prior to planting maize seeds, mycorrhiza, Azospirillum, nitrogen and phosphorus fertilizers were applied in all plots: a powder type Glomus intraradices biofertilizer was applied in strip form below the seeding rows. Azospirillum lipoferum $\left(2 \times 10^{8}\right)$ was also inoculated with seeds. Moreover, $75 \mathrm{~kg}^{*} \mathrm{ha}^{-1}$ nitrogen in the form of urea fertilizer and $50 \mathrm{~kg}^{*} \mathrm{ha}^{-1}$ phosphorus in the form of triplesuperphosphate fertilizer (recommended by the laboratory, based on the results of soil sample analysis) were added to plots. Elemental sulfur at the rate of $150 \mathrm{~kg}^{*} \mathrm{ha}^{-1}$ (powder form with $98 \%$ purity) was mixed with $3 \mathrm{~kg}^{*} \mathrm{ha}^{-1} T$. thiooxidans and then sulfur was mixed with soil.

Maize seeds (Zea mays L. var. popcorn KSC. 600) were planted on 19 May 2012, after being inoculated with Azospirillum, at the rate of 66,000 plants*ha- ${ }^{-1}$. This variety was used because it is less known and less cultivated in Iran. Irrigation was conducted after $70 \mathrm{~mm}$ evaporation from the evaporation pan. The field was irrigated a total of 21 times during the growing period, and amount of rainfall was $58.4 \mathrm{~mm}$.

Prior to harvest, ear leaf area and chlorophyll content were measured by the means of a leaf area meter and a chlorophyll meter model Opti-Science (CCM-200), respectively. Then 10 plants were harvested from the middle rows of each plot and grain yield was measured. To measure the absorption of nutrients, 5 other plants were harvested from each plot when grains were at dough stage and dried at $70{ }^{\circ} \mathrm{C}$ in an oven for 72 hours. Then samples were ground and analyzed. Nitrogen and protein were measured by Kjeldahl method and $\mathrm{P}$ was measured by spectrophotometry. Fe and $\mathrm{Zn}$ were also measured by atomic absorption.

Finally, data were tested for normality and were subjected to Proc GLM analysis using SAS software (SAS 9.1 2002). Duncan's multiple range test was also used to compare the means at $\mathrm{P} \leq 0.05$.

\section{Results and Discussion}

\section{The effect of vermicompost}

Analysis of variance showed a significant effect of vermicompost application on all measured traits in this experiment (Table 3). Vermicompost application improved plant growth and yield; increasing grain yield by $20.9 \%, 1000$ seed weight by $10.0 \%$, LAI by $10.3 \%$ and chlorophyll content by $17.6 \%$. Moreover, vermicompost was the only treatment in this experiment with significant effect on root colonization rate, increasing it by $20.1 \%$ (Table 4 ).

Vermicompost improved soil porosity, aeration, water holding capacity, microbial activity and consequently fertility (Dominguez, 2004; Singh

Table 2. Properties of the applied vermicompost.

\begin{tabular}{cccccccccccc}
\hline $\begin{array}{c}\text { Moisture } \\
(\%)\end{array}$ & $\begin{array}{c}\mathrm{EC} \\
\left(\mathrm{ds} * \mathrm{~m}^{-1}\right)\end{array}$ & $\begin{array}{c}\mathrm{OC} \\
(\%)\end{array}$ & $\begin{array}{c}\text { Total N } \\
(\%)\end{array}$ & $\begin{array}{c}\mathrm{P} \\
(\%)\end{array}$ & $\begin{array}{c}\mathrm{K} \\
(\%)\end{array}$ & $\begin{array}{c}\mathrm{Ca} \\
(\%)\end{array}$ & $\begin{array}{c}\mathrm{Mg} \\
(\%)\end{array}$ & $\begin{array}{c}\mathrm{Na} \\
(\%)\end{array}$ & $\begin{array}{c}\mathrm{Fe} \\
\left(\mathrm{mg}^{*} \mathrm{~kg}^{-1}\right)\end{array}$ & $\begin{array}{c}\mathrm{Zn} \\
\left(\mathrm{mg}^{*} \mathrm{~kg}^{-1}\right)\end{array}$ & $\begin{array}{c}\mathrm{Mn} \\
\left(\mathrm{mg}^{*} \mathrm{~kg}^{-1}\right)\end{array}$ \\
\hline 25 & 1.12 & 25 & 1.4 & 1.8 & 2.2 & 1 & 1.2 & 0.8 & 3,300 & $\begin{array}{c}\mathrm{Cu} \\
\left(\mathrm{mg}^{*} \mathrm{~kg}^{-1}\right)\end{array}$ \\
\hline
\end{tabular}


Table 3. Analysis of variance of the effect of treatments on the measured traits.

\begin{tabular}{|c|c|c|c|c|c|c|c|c|c|c|c|}
\hline \multirow[b]{2}{*}{ SOV } & \multirow[b]{2}{*}{$\mathrm{df}$} & \multicolumn{10}{|c|}{ Mean Squares } \\
\hline & & $\begin{array}{l}\text { Grain } \\
\text { yield }\end{array}$ & $\begin{array}{c}1000 \\
\text { seed } \\
\text { weight }\end{array}$ & LAI & $\mathrm{N}$ & $\mathrm{P}$ & $\mathrm{Fe}$ & $\mathrm{Zn}$ & Chlorophyll & Protein & Colonization \\
\hline Rep & 2 & ns & ns & $* *$ & ns & $\mathrm{ns}$ & ** & $* *$ & $\mathrm{~ns}$ & $\mathrm{~ns}$ & $\mathrm{~ns}$ \\
\hline V & 1 & $* *$ & $* *$ & $* *$ & $* *$ & $* *$ & $* *$ & $* *$ & $* *$ & $* *$ & $* *$ \\
\hline B & 1 & $* *$ & $*$ & $* *$ & $* *$ & $* *$ & $* *$ & $* *$ & $* *$ & $* *$ & $\mathrm{~ns}$ \\
\hline $\mathrm{F}$ & 1 & $* *$ & ns & $*$ & $\mathrm{~ns}$ & $\mathrm{~ns}$ & $* *$ & $\mathrm{~ns}$ & $* *$ & ns & ns \\
\hline Z & 1 & $* *$ & $\mathrm{~ns}$ & ns & $* *$ & $\mathrm{~ns}$ & ns & $* *$ & $*$ & $* *$ & ns \\
\hline VB & 1 & $* *$ & ns & ns & $\mathrm{ns}$ & $\mathrm{ns}$ & ns & $\mathrm{ns}$ & ns & ns & ns \\
\hline VF & 1 & ns & ns & ns & ns & ns & ns & ns & ns & ns & ns \\
\hline VZ & 1 & ns & ns & ns & ns & $\mathrm{ns}$ & ns & ns & ns & ns & ns \\
\hline $\mathrm{BF}$ & 1 & ns & ns & ns & ns & $\mathrm{ns}$ & $*$ & ns & ns & ns & ns \\
\hline BZ & 1 & ns & ns & ns & ns & $\mathrm{ns}$ & ns & ns & ns & ns & ns \\
\hline FZ & 1 & ns & $\mathrm{ns}$ & ns & ns & $\mathrm{ns}$ & ns & ns & ns & ns & ns \\
\hline VBF & 1 & $\mathrm{~ns}$ & $\mathrm{~ns}$ & $\mathrm{~ns}$ & $\mathrm{~ns}$ & $\mathrm{~ns}$ & ns & $\mathrm{ns}$ & ns & ns & ns \\
\hline VBZ & 1 & ns & ns & ns & ns & $\mathrm{ns}$ & ns & $\mathrm{ns}$ & ns & ns & ns \\
\hline VFZ & 1 & $\mathrm{~ns}$ & $\mathrm{~ns}$ & $\mathrm{~ns}$ & $\mathrm{~ns}$ & $\mathrm{~ns}$ & $\mathrm{~ns}$ & $\mathrm{~ns}$ & $\mathrm{~ns}$ & $\mathrm{~ns}$ & $\mathrm{~ns}$ \\
\hline BFZ & 1 & $\mathrm{~ns}$ & ns & $\mathrm{ns}$ & ns & $\mathrm{ns}$ & ns & ns & ns & $\mathrm{ns}$ & ns \\
\hline VBFZ & 1 & ns & ns & ns & ns & ns & ns & ns & $\mathrm{ns}$ & ns & $\mathrm{ns}$ \\
\hline Error & 30 & $292,064.31$ & 32,056 & $2,337.24$ & 0.02 & 0.001 & 86,644 & 26,268 & 12,992 & 0.651 & 12,125 \\
\hline $\mathrm{CV}(\%)$ & - & 6.56 & 3.01 & 7.50 & 8.25 & 11.6 & 11.59 & 13.1 & 5.44 & 8.37 & 8.68 \\
\hline
\end{tabular}

V, vermicompost; B, Thiobacillus; F, iron; Z, zinc.

ns, nonsignificant; **, significant at $\mathrm{P} \leq 0.01$; *, significant at $\mathrm{P} \leq 0.05$.

Table 4. Effects of vermicompost (without, $\mathrm{V}_{0}$; with, $\mathrm{V}_{1}$ ), Thiobacillus (without, $\mathrm{B}_{0}$; with, $\mathrm{B}_{1}$ ), iron spraying (without, $\mathrm{F}_{0}$; with, $\mathrm{F}_{1}$ ) and zinc spraying (without, $\mathrm{Z}_{0}$; with, $\mathrm{Z}_{1}$ ) on the measured traits.

\begin{tabular}{cccccrc}
\hline Treatments & Grain yield $\left(\mathrm{kg}^{*} \mathrm{ha}^{-1}\right)$ & 1000 seed weight $(\mathrm{g})$ & LAI $\left(\mathrm{cm}^{2}\right)$ & Chlorophyll & Protein $(\%)$ & Colonization $(\%)$ \\
\hline $\mathrm{V}_{0}$ & $7,457.2 \mathrm{~b}$ & $178.5 \mathrm{~b}$ & $613.0 \mathrm{~b}$ & $60.7 \mathrm{~b}$ & $8.95 \mathrm{~b}$ & $36.42 \mathrm{~b}$ \\
$\mathrm{~V}_{1}$ & $9,015.8 \mathrm{a}$ & $196.4 \mathrm{a}$ & $675.9 \mathrm{a}$ & $71.4 \mathrm{a}$ & $10.33 \mathrm{a}$ & $43.74 \mathrm{a}$ \\
$\mathrm{B}_{0}$ & $7,731.3 \mathrm{~b}$ & $185.5 \mathrm{~b}$ & $621.1 \mathrm{~b}$ & $62.7 \mathrm{~b}$ & $9.14 \mathrm{~b}$ & $40.0 \mathrm{a}$ \\
$\mathrm{B}_{1}$ & $8,741.7 \mathrm{a}$ & $189.3 \mathrm{a}$ & $667.8 \mathrm{a}$ & $69.5 \mathrm{a}$ & $10.14 \mathrm{a}$ & $40.1 \mathrm{a}$ \\
$\mathrm{F}_{0}$ & $8,004.9 \mathrm{~b}$ & $186.8 \mathrm{a}$ & $630.1 \mathrm{~b}$ & $63.7 \mathrm{~b}$ & $9.49 \mathrm{a}$ & $40.0 \mathrm{a}$ \\
$\mathrm{F}_{1}$ & $8,468.0 \mathrm{a}$ & $188.1 \mathrm{a}$ & $658.81 \mathrm{a}$ & $68.5 \mathrm{a}$ & $9.78 \mathrm{a}$ & $40.0 \mathrm{a}$ \\
$\mathrm{Z}_{0}$ & $7,918.0 \mathrm{~b}$ & $186.6 \mathrm{a}$ & $639.3 \mathrm{a}$ & $65.0 \mathrm{~b}$ & $9.30 \mathrm{~b}$ & $40.0 \mathrm{a}$ \\
$\mathrm{Z}_{1}$ & $8,555.0 \mathrm{a}$ & $188.3 \mathrm{a}$ & $649.6 \mathrm{a}$ & $67.2 \mathrm{a}$ & $9.97 \mathrm{a}$ & $40.1 \mathrm{a}$ \\
\hline
\end{tabular}

Means in a column followed by the same letter are not significantly different at $\mathrm{P} \leq 0.01$.

et al., 2008; Chander et al., 2013). The improving effect of vermicompost on root colonization rate in our experiment may also be attributed to the effects of vermicompost on soil physical, chemical and biological properties which facilitated the activity of mycorrhizal fungi. In addition, vermicompost is a source of plant growth regulators and phytohormones such as humic acid, auxin, gibberellin and cytokinin (Atiyeh et al., 2002; Singh et al., 2008). Atiyeh et al. (2002) extracted humic acid from pig manure vermicompost and mixed it with a soilless culture medium containing tomato seedlings. They observed that the humic acid increased tomato plant height, leaf area, shoot dry weight and root dry weight. They attributed the improvement of plant growth to the hormone-like activity of humic acids derived from the vermicomposts. Canellas et al. (2002) also found that humic acids isolated from earthworm compost promoted root elongation and lateral root emergence of maize roots. Lazcano et al. (2011) tested the effect of vermicompost on sweet corn hybrids and reported that the treatment significantly improved plant growth, marketable yield and the quality of ears. Singh et al. (2008) also tested the 
effect of vermicompost on strawberry and found that vermicompost application increased plant spread by $10.7 \%$, leaf area by $23.1 \%$, dry matter by $20.7 \%$ and fruit yield by $32.7 \%$. Moreover, they found that the quality of the fruits was improved (higher TSS and ascorbic acid and lower acidity) when vermicompost was applied. Pant (2009) reported that different vermicompost tea treatments increased shoot yield in Brassica rapa.

In addition to the improvement of maize growth and yield, vermicompost had also an improving effect on maize biofortification. Results of this experiment showed that vermicompost application increased the content of $\mathrm{N}(17.6 \%), \mathrm{P}(41.7 \%), \mathrm{Fe}$ (12.7\%), $\mathrm{Zn}(29.2 \%)$ and protein $(15.4 \%)$ compared to the control (Table 4, Figure 1, Figure 2). As discussed, the effects of vermicompost on maize quality may be attributed to its effect on soil

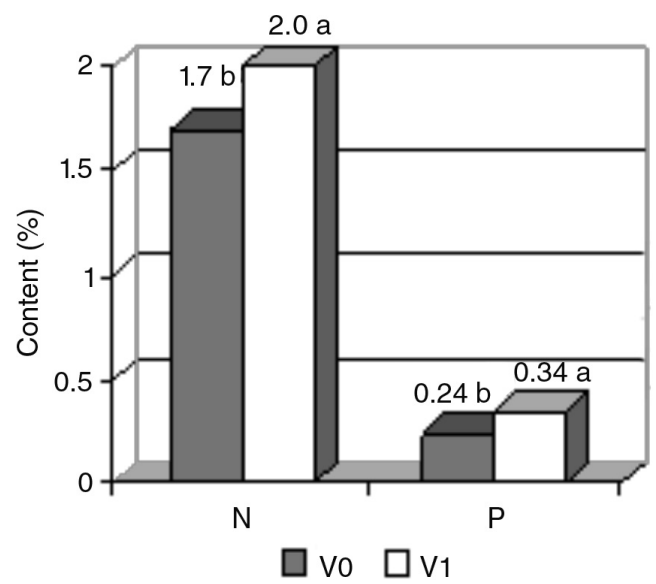

Figure 1. The effect of vermicompost $\left(\mathrm{V}_{0}\right.$, control; $\left.\mathrm{V}_{1}, 2 \mathrm{t} * \mathrm{ha}^{-1}\right)$ on macronutrient content.

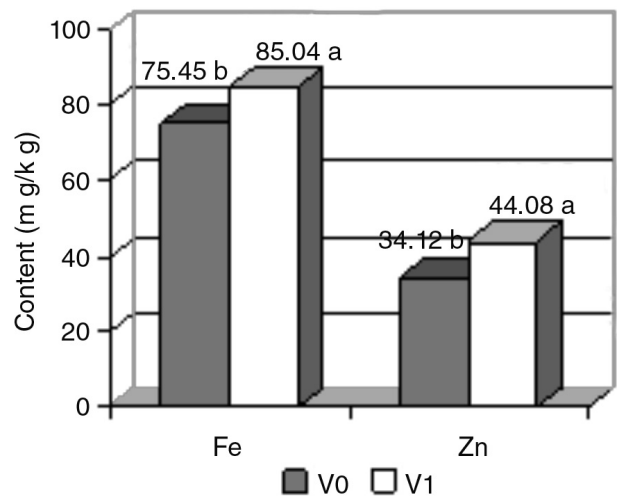

Figure 2. The effect of vermicompost $\left(\mathrm{V}_{0}\right.$, control; $\left.\mathrm{V}_{1}, 2 \mathrm{t} * \mathrm{ha}^{-1}\right)$ on micronutrient content. physical-chemical properties and its ability to release plant growth regulators, phytohormones and mineral nutrients. On the other hand, vermicompost, like other organic matter, may have an effect on the availability of mineral nutrients in soil for plant roots. As an example, higher content of water soluble phosphorus in soil as the result of vermicompost application was reported by Mohammady Aria et al. (2010). They observed that vermicompost had a significantly positive effect on $\mathrm{P}$ release from rock phosphate. Atiyeh et al. (2001) reported that vermicompost application reduced soil $\mathrm{pH}$ and increased microbial activity, which may consequently affected the availability of nutrients for plant roots. Pant (2009) also reported that vermicompost tea application resulted in higher $\mathrm{N}, \mathrm{P}, \mathrm{K}, \mathrm{Ca}$ and $\mathrm{Mg}$ content in Brassica rapa tissue. In another experiment, Wang et al. (2010) found that application of vermicompost increased nutrient content, soluble sugars, soluble protein, vitamin $\mathrm{C}$, total phenols and total flavonoids in Chinese cabbage (Brassica campestris). Results also showed that the interaction of vermicompost $\times$ Thiobacillus had significant effect on grain yield. In this interaction, the highest grain yield (9263.7 kg*ha-1) was obtained with vermicompost application $\times$ Thiobacillus inoculation (Figure 3 ).

\section{The effect of Thiobacillus thiooxidans inoculation}

Results indicated that inoculating maize seeds with Thiobacillus thiooxidans significantly affected nearly all measured traits including yield, LAI, chlorophyll content, protein content and

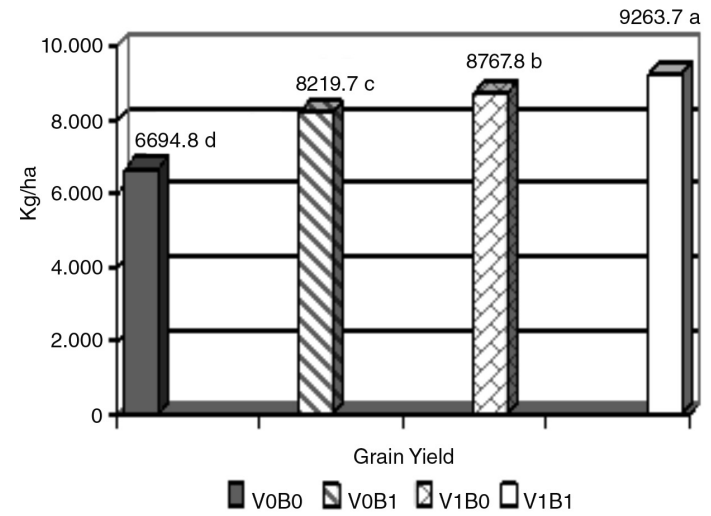

Figure 3. The effects of the interaction of vermicompost $\left(\mathrm{V}_{0}\right.$, control; $\left.\mathrm{V}_{1}, 2 \mathrm{t}^{*} \mathrm{ha}^{-1}\right) \times$ Thiobacillus $\left(\mathrm{B}_{0}\right.$, control; $\mathrm{B}_{1}$, inoculated $)$ on grain yield. 
nutrient content; the effect was not significant on colonization rate (Table 3 ). The inoculation increased grain yield, LAI and chlorophyll content by $13.1 \%, 7.5 \%$ and $10.8 \%$, respectively. The inoculation was also effective on biofortification of maize; increasing $\mathrm{N}(9.0 \%), \mathrm{P}(24.0 \%), \mathrm{Fe}$ (12.1\%), $\mathrm{Zn}(17.5 \%)$ and protein content $(10.9 \%)$ compared with the non-inoculated control (Table 4 , Figure 4, Figure 5).

The interaction of Thiobacillus $\times \mathrm{Fe}$ spraying had significant effect only on grain Fe content (Table 3 and Figure 6).

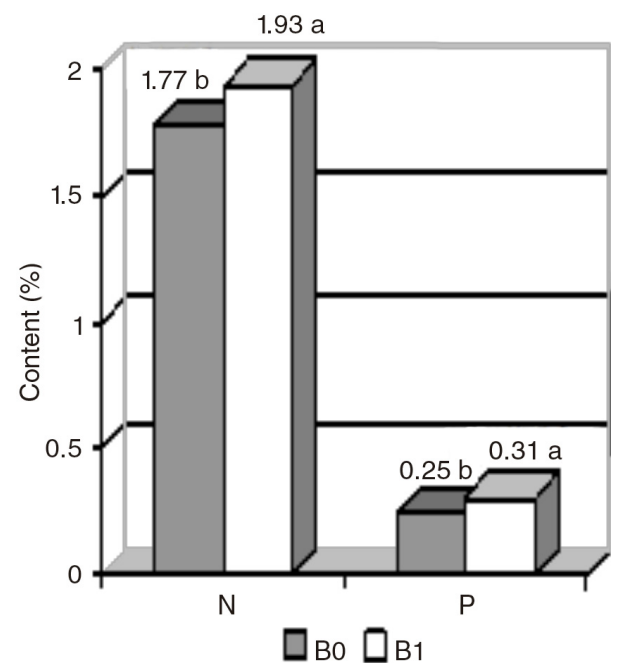

Figure 4. The effect of Thiobacillus $\left(\mathrm{B}_{0}\right.$, control; $\mathrm{B}_{1}$, inoculated) on macronutrient content.

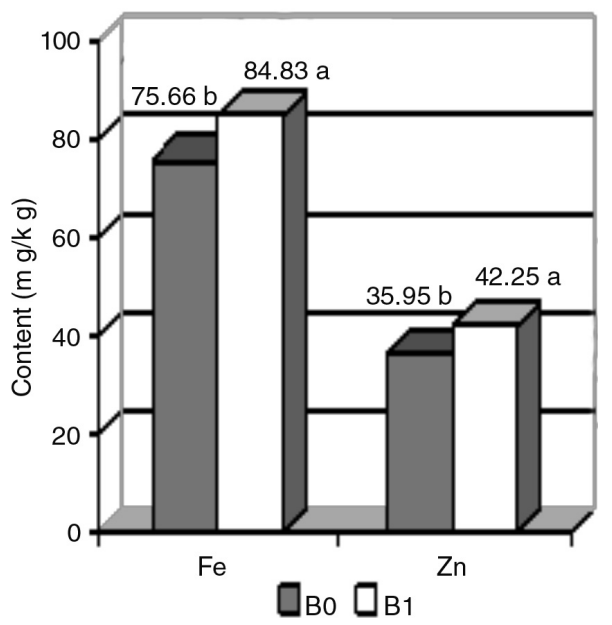

Figure 5. The effect of Thiobacillus $\left(\mathrm{B}_{0}\right.$, control; $\mathrm{B}_{1}$, inoculated) on micronutrient content.

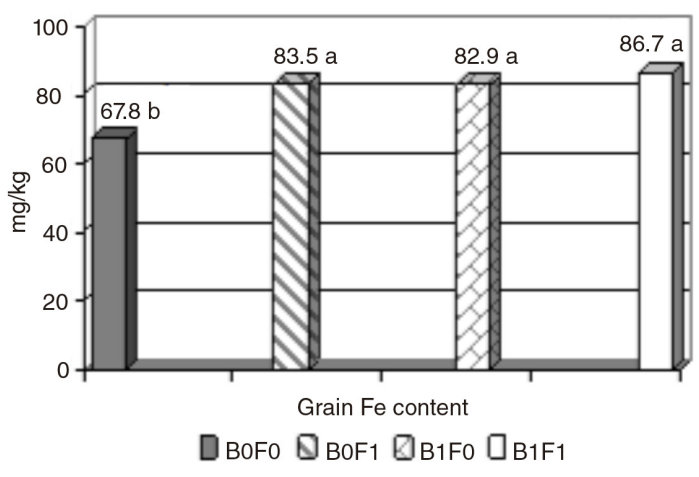

Figure 6. The effects of the interaction of Thiobacillus $\left(\mathrm{B}_{0}\right.$, control; $B_{1}$, inoculated $) \times \mathrm{Fe}$ spraying $\left(\mathrm{F}_{0}\right.$, control; $\mathrm{F}_{1}, \mathrm{Fe}$ sprayed $)$ on grain Fe content.

Thiobacillus receives energy by biological sulfur oxidation. This increases the available $\mathrm{S}$ content in the rhizosphere, lowering soil $\mathrm{pH}$ due to sulfuric acid production which consequently increases the availability of other elements to plant roots (Stamford et al., 2002; Killham, 2004). Also, some Thiobacillus species are reported to have the ability to produce gibberellin or gibberellin-like substances (Gairola et al., 1972). These features make Thiobacillus beneficial to plants. Aria et al. (2010) reported that Thiobacillus thiooxidans inoculation increased water soluble phosphorus in soil by releasing it from hard rock phosphate. Shata et al. (1992) also reported that inoculating maize and wheat plants with Thiobacillus increased phosphorus content in plant tissues by 3 times compared to non-inoculated plants. Anandham and Sridar (2004) found an improvement in oil content of groundnut seed when inoculated with Thiobacillus bacterium. Mostafavian et al. (2008) tested the inoculation of soybean with Thiobacillus and reported that the inoculation increased grain yield, oil yield and protein yield. The improvement of soybean grain yield and grain protein content as the result of Thiobacillus inoculation was also reported by Shinde et al. (2004). The effect of Thiobacillus inoculation on plant yield is observed in other experiments (Sharma, 2003; Balloei et al., 2009). As the results of this experiment show (Table 3), there was a positive interaction between adding vermicompost and using Thiobacillus bacterium on grain yield. Vermicompost, by altering physicochemical and biological properties of soil positively affects the Thiobacillus activity; plants absorbed more nutrients and finally yielded more. 


\section{The effect of $\mathrm{Fe}$ and $\mathrm{Zn}$ foliar application}

Mean comparisons showed that Fe spraying increased grain yield by $5.8 \%$, LAI by $4.6 \%$ and chlorophyll content by $7.5 \%$ (Table 4). Results also showed that foliar application of $\mathrm{Zn}$ significantly affected grain yield and chlorophyll content (Table 3). $\mathrm{Zn}$ spraying increased grain yield by $8.0 \%$ and chlorophyll content by $3.4 \%$ (Table 4 ).

Iron and zinc are two essential micronutrients playing vital roles in growth and development of plants. Iron is involved in plant metabolism, synthesis of chlorophyll and photosynthesis; it is a component of many enzymes and has structural role in hemetype and other proteins (Wiedenhoeft, 2006; Fageria, 2009). Results of our experiment showed that $\mathrm{Fe}$ foliar application increased chlorophyll content by $7.5 \%$ (Table 4); revealing the role of iron in chlorophyll synthesis. Zinc is a heavy metal micronutrient playing roles in enzyme structure and activation, chlorophyll synthesis, protein synthesis and $\mathrm{N}$ metabolism in plants (Wiedenhoeft, 2006; Fageria, 2009). The effect of $\mathrm{Zn}$ on chlorophyll and protein synthesis was also observed in our experiment; $\mathrm{Zn}$ application increased chlorophyll content by $3.4 \%$ and protein content by $7.2 \%$ (Table 4 ).

The role of $\mathrm{Fe}$ and $\mathrm{Zn}$ nutrition on structural, physiological and biochemical aspects of plants is well documented. There are various reports regarding the effect of foliar micronutrient application on enhancement of chlorophyll concentration in chlorotic leaves of plants such as tobacco (Fernandez et al., 2004) and pears (Alvarez-Fernandez et al., 2004). Clearly, improvement of plant health results in higher yield and quality. This was shown in our experiment, as $\mathrm{Fe}$ and $\mathrm{Zn}$ application increased grain yield by $5.8 \%$ and $8.04 \%$, respectively (Table 4 ). Zhang et al. (2013) reported that applying high concentrations of $\mathrm{Fe}$ and $\mathrm{Zn}$ to ginseng (Panax ginseng C.A. Mey) leaves increased root yield and quality. Pareek and Poonia (2011) found 14.8\% and $11.2 \%$ enhancement in pod and haulm yield of groundnut as the result of foliar Fe application. Yuan et al. (2012) found an average of $14.5 \%$ enhancement in $\mathrm{Fe}$ concentration of different rice cultivars. They also reported improvement in grain yield, protein content and total amino acid content as the result of $\mathrm{Fe}$ and $\mathrm{Zn}$ spraying. MovahhedyDehnavy (2009) also reported that Fe and Zn foliar application improved yield and quality of safflower (Carthamus tinctorius L.).
In some cases micronutrient application may not result in noticeable yield improvement. Unfortunately, today's agricultural systems are designed to increase the production rate and profits of farmers or agricultural industries; there has been very little effort to improve human health. Deficiency of micronutrients (mainly $\mathrm{Fe}$ and $\mathrm{Zn}$ ) in plants is responsible for many human health issues, especially in developing countries and poor societies with cereal-based diets (Welch, 1993; Fageria, 2009). Biofortification studies in our experiment showed that although $\mathrm{Fe}$ application had no significant effect on plant macronutrient content,; it significantly increased Fe content by $12.9 \%$ (Figure 7, Figure 8). Moreover, application of $\mathrm{Zn}$ significantly increased $\mathrm{N}$ by $6.7 \%, \mathrm{Zn}$ by $12.6 \%$ and protein content by $7.2 \%$ (Table 4, Figure 9, Figure 10). Fang et al.

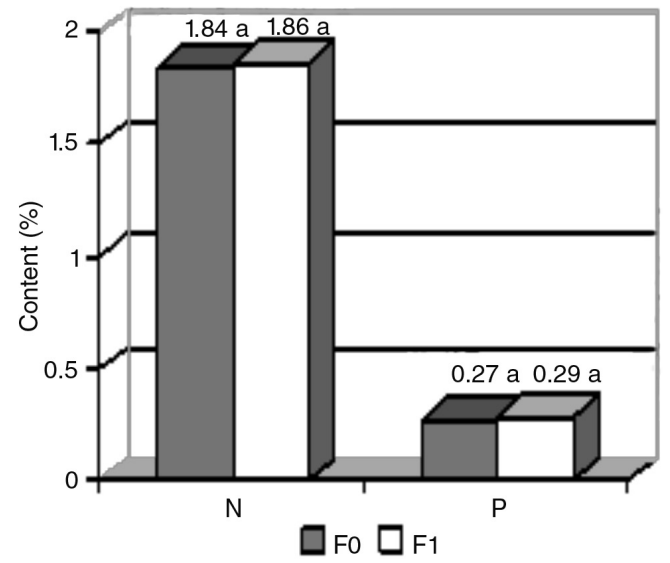

Figure 7. The effect of foliar Fe application $\left(\mathrm{F}_{0}\right.$, control; $\mathrm{F}_{1}, \mathrm{Fe}$ sprayed) on macronutrient content.

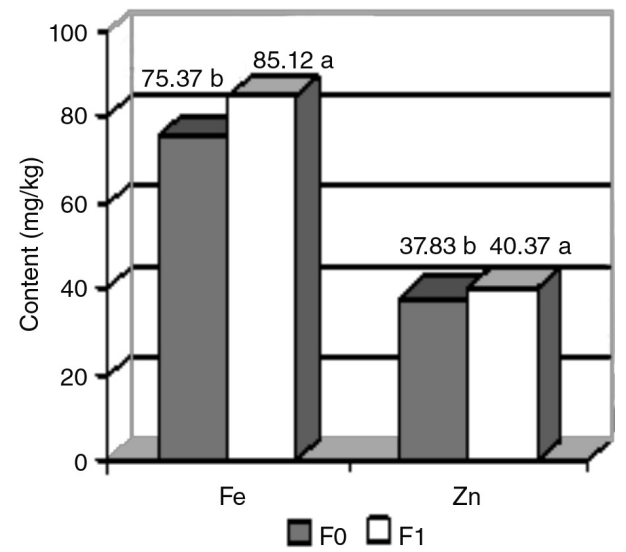

Figure 8. The effect of foliar Fe application $\left(\mathrm{F}_{0}\right.$, control; $\mathrm{F}_{1}, \mathrm{Fe}$ sprayed) on micronutrients content. 


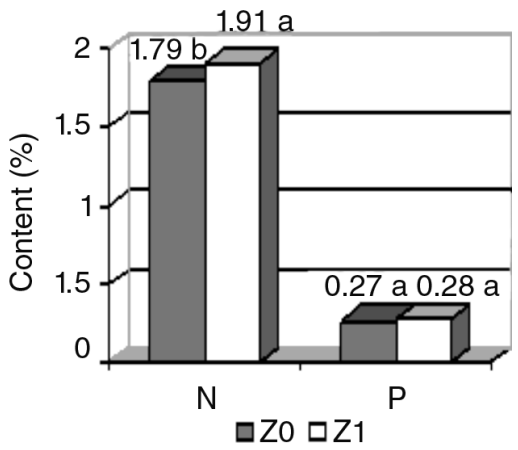

Figure 9. The effect of foliar $\mathrm{Zn}$ application $\left(\mathrm{Z}_{0}\right.$, control; $\mathrm{Z}_{1}, \mathrm{Zn}$ sprayed) on macronutrient content.

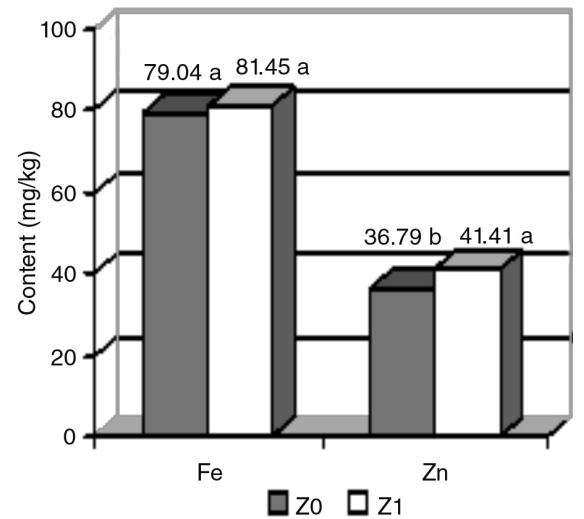

Figure 10. The effect of foliar $\mathrm{Zn}$ application $\left(\mathrm{Z}_{0}\right.$, control; $\mathrm{Z}_{1}$, $\mathrm{Zn}$ sprayed) on micronutrient content.

(2008) reported that foliar application of $\mathrm{Fe}, \mathrm{Zn}$ and Se had significant effect on rice protein, ash, $\mathrm{Fe}$ and Zn content; no significant effect was observed on plant yield. Zhang et al. (2010) also reported that although foliar application of $\mathrm{Fe}$ and $\mathrm{Zn}$ had no effect on winter wheat biomass and grain yield; however, the treatments increased grain $\mathrm{Fe}$ concentration by $7-36 \%$ and $\mathrm{Zn}$ concentration by $28-68 \%$ depending on the cultivar. From these findings it might be concluded that $\mathrm{Fe}$ and $\mathrm{Zn}$ foliar application have slight effect on plant yield and farmer income; however, attention must be paid to their effect on the biofortification features and product quality. So treating plant with micronutrients, although might be costly, is recommended to promote human health and to deal with the micronutrient malnutrition that affects more than half the world population.

\section{Conclusion}

Nutrient management is one of the most important factors in successful crop production; thus in this experiment we tried to take advantage of soil microorganisms to find a suitable method for sustainable crop nutrient management instead of chemical methods. In recent years, increased application of chemical inputs to agricultural fields has caused several environmental and health issues and reduced the quality of products. As the results of this experiment showed, integrated nutrient management with lower dependency on chemical fertilizers is a promising method to reach sustainable and healthy production and food safety.

\section{Acknowledgements}

The authors gratefully acknowledge Islamic Azad University, Tabriz Branch- Iran, for their field and laboratory support.

\section{Literature Cited}

Álvarez-Fernández, A.; García-Lavina, P.; Fidalgo, C.; Abadia, J.; Abadia, A.

2004. Foliar fertilization to control iron chlorosis in pear (Pyrus communis L.) trees. Plan and Soil, 263, 5-15.

Anandham, R.; Sridar, R.

2004. Use of sulfur bacteria for increased yield and oil content of groundnut. In: S. Kannaiyan, K. Kumar, K. Govindarajan, eds. (2004). Biofertilizers technology. India: Scientific Publishers, pp. 365-371.

Aria, M.M.; Lakzian, A.; Haghnia, G.H.; Berenji, A.R.; Besharati, H.; Fotovat, A.

2010. Effect of Thiobacillus, sulfur, and vermicompost on the water-soluble phosphorus of hard rock phosphate. Bioresource Technology, 101, 551-554.
Atiyeh, R.M.; Edwards, C.A.; Subler, S.; Metzger, J.D. 2001. Pig manure vermicompost as a component of a horticultural bedding plant medium: effects on physicochemical properties and plant growth. Bioresource Technology, 78, 11-20.

Atiyeh, R.M.; Lee, S.S.; Edwards, C.A.; Arancon, N.Q.; Metzger, J. 2002. The influence of humic acid derived from earthwormprocessed organic waste on plant growth. Bioresource Technology, 84, 7-14.

Balloei, F.; Ardakani, M.R.; Rejali, F.; Ramzanpoor, M.R.; Alizade, G.R.; Mohebbati, F.

2009. Effect of Thiobacillus and mycorrhiza fungi under different levels of sulfur on yield and yield components of soybean. Proceedings of international symposium on root research and applications. Vienna, Austria, September 2-4. 
Bouis, H.E.; Welch, R.M.

2010. Biofortification - a sustainable agricultural strategy for reducing micronutrient malnutrition in the global south. Crop Science, 50, 20-32.

Cakmak, I.

2008. Enrichment of cereal grains with zinc: Agronomic or genetic biofortification? Plant and Soil, 302, 1-17.

Canellas, L.P., Olivares, F.L., Okorokova-Façanha, A.L.,

Façanha, A.R.

2002. Humic acids isolated from earthworm compost enhance root elongation, lateral root emergence, and plasma membrane $\mathrm{H}^{+}$-ATPase activity in maize roots. Plant Physiology, 130, 1951-1957.

Chander, G.; Wani, S.P.; Sahrawat, K.L.; Kamdi, P.J.; Pal, C.K.;

Pal, D.K.; Mathur, T.P.

2013. Balanced and integrated nutrient management for enhanced and economic food production: case study from rainfed semi-arid tropics in India. Archives of Agronomy and Soil Science, 59, 1643-1658.

Cho, J.Y.; Son, J.G.; Song, C.H.; Hwang, S.A.; Lee, Y.M.; Jeong,

S.Y.; Chung, B.Y.

2008. Integrated nutrient management for environmentalfriendly rice production in salt-affected rice paddy fields of Saemangeum reclaimed land of South Korea. Paddy and Water Environment, 6, 263-273.

Domínguez, J.

2004. State of the art and new perspectives on vermicomposting research. In: C. A. Edwards, ed. (2004). Earthworm ecology. $2^{\text {nd }}$ ed. Boca Raton, FL: CRC Press, pp. 401-424.

Fageria, N.K.

2009. The use of nutrients in crop plants. CRC Press, USA.

Fang, Y.; Wang, L.; Xin, Z.; Zhao, L.; An, X.; Hu, Q.

2008. Effect of foliar application of zinc, selenium, and iron fertilizers on nutrients concentration and yield of rice grain in China. Journal of Agricultural and Food Chemistry, 56, 2079-2084.

Fernández, V.; Winkelmann, G.; Ebert, G.

2004. Iron supply to tobacco plants through foliar application of iron citrate and ferric dimerum acid. Physiologia Plantarum, 122, 380-385.

Gairola, C.; Bhalla, P.R.; Sabharwal, P.S.; Aleem, M.I.H. 1972. Production of gibberellin-like substances by an autotrophically grown Thiobacillus. Planta, 106, 177-180.

Garnier, M.; Recanatesi, F.; Nicoletta Ripa, M.; Leone, A.

2010. Agricultural nitrate monitoring in a lake basin in Central Italy: a further step ahead towards an integrated nutrient management aimed at controlling water pollution. Environmental Monitoring and Assessment, 170, 273-286.

Gopalasundaram, P.; Bhaskaran, A.; Rakkiyappan, P.

2012. Integrated nutrient management in sugarcane. Sugar Tech, 14, 3-20.

Killham, K.

1994. Soil ecology. Cambridge University Press, UK.

Lazcano, C.; Revilla, P.; Malvar, R.A.; Dominguez, J.

2011. Yield and fruit quality of four sweet corn hybrids (Zea mays) under conventional and integrated fertilization with vermicompost. Journal of the Science of Food and Agriculture, 91, 1244-1253.

Mostafavian, S.R.; Pirdashti, H.; Ramzanpour, M.R.; Andarkhor, A.A.; Shahsavari, A.

2008. Effect of mycorrhizae, Thiobacillus and sulfur nutrition on the chemical composition of soybean [Glycine $\max (\mathrm{L})$.
Merr. seed. Pakistan Journal of Biological Sciences, 11, 826-835.

Movahhedy-Dehnavy, M.; Modarres-Sanavy, S.A.M.; MokhtassiBidgoli, A.

2009. Foliar application of zinc and manganese improves seed yield and quality of safflower (Carthamus tinctorius L.) grown under water deficit stress. Industrial Crops Production, 30, 82-92.

Pant, A.P.; Radovich, T.J.K.; Hue, N.V.; Talcott, S.T.; Krenek, K.A. 2009. Vermicompost extracts influence growth, mineral nutrients, phytonutrients and antioxidant activity in pak choi (Brassica rapa cv. Bonsai, Chinensis group) grown under vermicompost and chemical fertilizer. Journal of the Science of Food and Agriculture, 89, 2383-2392.

Pareek, N.K.; Poonia, B.L.

2011. Effect of FYM, nitrogen and foliar spray of iron on productivity and economics of irrigated groundnut in an arid region of India. Archives of Agronomy and Soil Science, 57, 523-531.

Prasad, P.V.V.; Satyanarayana, V.; Murthy, V.R.K.; Boote, K.J. 2002. Maximizing yield in rice-groundnut cropping sequence through integrated nutrient management. Field Crops Research, 75, 9-21.

SAS Institute

2002. The SAS System for Windows. Release 9.1. The Institute Cary, USA.

Sawan, Z.M.; Hafez, S.A.; Basyony, A.E.

2001. Effect of nitrogen fertilization and foliar application of plant growth retardants and zinc on cottonseed, protein and oil yields and oil properties of cotton. Journal of Agronomy and Crop Science, 186, 183-191.

Sharma, A.K.

2003. Biofertilizers for sustainable agriculture. Agrobios, India.

Shata, S.M.; Selim, A.M.; Abdel-Fattah, A.

1992. Growth response of corn and wheat to sulfur-oxidizing bacteria under certain soil and irrigation conditions. Proceedings of the Middle East sulfur symposium. Cairo, Egypt.

Shinde, D.B.; Kadam, R.M.; Jadhav, A.C.

2004. Effects of sulfur oxidizing micro-organisms on growth of soybean. Journal of Maharashtra agricultural universities, 29, 305-307.

Singh, R.; Sharma, R.R.; Kumar, S.; Gupta, R.K.; Patil, R.T.

2008. Vermicompost substitution influences growth, physiological disorders, fruit yield and quality of strawberry (Fragaria $x$ ananassa Duch.). Bioresource Technology, 99, 8507-8511.

Stamford, M.P.; Silva, A.J.N.; Freitas, A.D.S.; Araujo Filho, J.T. 2002. Effect of sulfur inoculated with Thiobacillus on soil salinity and growth of tropical tree legumes. Bioresource Technology, 81, 53-59.

Tisdale, S.L.; Nelson, W.L.; Beaton, J.D.

1984. Soil fertility and fertilizers. 4th ed. McMillan Publishing Company, New York.

Tomati, U.; Galli, E.; Grappelli, A.; Dihena, G.

1990. Effect of earthworm casts on protein synthesis in radish (Raphanus sativum) and lettuce (Lactuca sativa) seedlings. Biology and Fertility of Soils, 9, 288-289.

Wang, D.; Shi, Q.; Wang, X.; Wei, M.; Hu, J.; Liu, J.; Yang, F. 2010. Influence of cow manure vermicompost on the growth, metabolite contents, and antioxidant activities of Chinese 
cabbage (Brassica campestris ssp. Chinensis). Biology and Fertility of Soils, 46, 689-696.

\section{Welch, R.M.}

1993. Zinc concentrations and forms in plants for human and animals. In: A. D. Robson, ed. (1993). Zinc in soil and plants. Dordrecht: Kluwer Academic Publishers, pp. 183-195.

Wiedenhoeft, A.C.

2006. Plant nutrition. Chelsea House Publishers, USA.

Yuan, L.; Wu, L.; Yang, C.; Lv, Q.

2012. Effects of iron and zinc foliar applications on rice plants and their grain accumulation and grain nutritional quality. Journal of the Science of Food and Agriculture, 93, 254-261.

Zhang, H.; Yang, H.; Wang, Y.; Gao, Y.; Zhang, L.

2013. The response of ginseng grown on farmland to foliarapplied iron, zinc, manganese and copper. Industrial Crops Production, 45, 388-394.

Zhang, Y.; Shi, R.; Rezaul, K.M.; Zhang, F.; Zou, C.

2010. Iron and zinc concentrations in grain and flour of winter wheat as affected by foliar application. Journal of Agricultural and Food Chemistry, 58, 12268-12274. 